\title{
Synthesis, characterization, and high gas permeability of poly(diarylacetylene)s having fluorenyl groups
}

\section{AUTHOR(S):}

Fukui, Akito; Hattori, Kyohei; Hu, Yanming;

Shiotsuki, Masashi; Sanda, Fumio; Masuda, Toshio

\section{CITATION:}

Fukui, Akito ...[et al]. Synthesis, characterization, and high gas permeability of poly(diarylacetylene)s having fluorenyl groups. Polymer 2009, 50(17): 4159-4165

\section{ISSUE DATE:}

2009-08-12

URL:

http://hdl.handle.net/2433/123403

\section{RIGHT:}

Copyright (C) 2009 Elsevier; この論文は出版社版でありません。引用の 際には出版社版をご確認ご利用ください。; This is not the published version. Please cite only the published version. 


\section{A regular article for POLYMER}

Synthesis, Characterization, and High Gas Permeability of Poly(diarylacetylene)s Having Fluorenyl Groups

Akito Fukui, Kyohei Hattori, Yanming Hu, Masashi Shiotsuki, Fumio Sanda, Toshio Masuda*

Department of Polymer Chemistry, Graduate School of Engineering, Kyoto University, Katsura Campus, Nishikyo-ku. Kyoto 615-8510, Japan

* Corresponding author. Present Address: Department of Environmental and Biological Chemistry, Fukui University of Technology, 3-6-1 Gakuen, Fukui 910-8505, Japan Tel: +81-776-29-2714; fax: +81-776-29-2714

E-mail:masuda@fukui-ut.ac.jp 


\section{ABSTRACT}

Diarylacetylenes having fluorenyl groups and other substituents (trimethylsilyl, $t$-butyl, bromine, fluorine) $(\mathbf{1 a}-\mathbf{l})$ were polymerized with $\mathrm{TaCl}_{5}-n-\mathrm{Bu}_{4} \mathrm{Sn}$. Monomers $\mathbf{1 a}-\mathbf{l}$ produced high molecular weight polymers 2 a-l $\left(M_{\mathrm{w}} 5.1 \times 10^{5}-1.3 \times 10^{6}\right)$ in $12-59 \%$ yields. All of the polymers were soluble in common organic solvents, and gave tough free-standing membranes by the solution casting method. The onset temperatures of weight loss of polymers $\mathbf{2 a}-\mathbf{l}$ in air were over $400{ }^{\circ} \mathrm{C}$, indicating considerably high thermal stability. All the polymer membranes showed high gas permeability; e.g., the oxygen permeability coefficient $\left(\mathrm{PO}_{2}\right)$ of $\mathbf{2 a}$ was as large as 4800 barrers. Membrane 2d possessing two fluorine atoms at meta and para positions of the phenyl ring showed the highest oxygen permeability $\left(\mathrm{PO}_{2}=6600\right.$ barrers $)$ among the present polymers.

Keywords: Gas Permeability; Membranes; Polyacetylene 


\section{Introduction}

Disubstituted acetylenes can be polymerized with group 5 and 6 transition metal catalysts to provide substituted polyacetylenes, which have alternating carbon-carbon double bonds along the main chain [1]. It is known that some of these polymers, especially those having bulky substituents, exhibit high gas permeability among all the existing polymers [2]. For example, poly(1-trimethylsilyl-1-propyne) [poly(TMSP)], which is obtained by the polymerization of the corresponding monomer with Ta- and Nb-based catalysts, is soluble in common organic solvents, provides a free-standing membrane by solution casting, and shows extremely high gas permeability [2f, 3]; its oxygen permeability coefficient $\left(\mathrm{PO}_{2}\right)$ reaches about 10000 barrers [1 barrer $\left.=1 \times 10^{-10} \mathrm{~cm}^{3}(\mathrm{STP}) \mathrm{cm} /\left(\mathrm{cm}^{2} \mathrm{~s} \mathrm{cmHg}\right)\right]$. The high gas permeability of poly(TMSP) is attributable to the presence of microvoids in the polymer matrix based on the stiff main chain composed of alternating double bonds and the bulky spherical trimethylsilyl groups.

Poly(diphenylacetylene) derivatives are another important type of highly gas-permeable polymers. For instance, poly[1-phenyl-2-( $p$-trimethylsilyl)phenylacetylene] [poly(TMSDPA)] exhibits high gas permeability as well as thermal stability [4]. The $\mathrm{PO}_{2}$ value of this polymer is as high as 1500 barrers, which is ca. twice larger than that of the most gas-permeable rubbery polymer, poly(dimethylsiloxane) [poly(DMS)] [5], and the onset temperature of weight loss in air $\left(T_{0}\right)$ is $420{ }^{\circ} \mathrm{C}$ [4], which is clearly higher than that of poly(TMSP) $\left(300{ }^{\circ} \mathrm{C}\right)[3 \mathrm{~b}]$. The superior combination of high gas permeability and high thermal stability makes poly(diphenylacetylene)s as promising candidates for gas separation membranes. 
In previous studies, we have investigated the synthesis and gas permeation properties of several poly(diarylacetylene)s [6]. The polymerization of 1-(2-fluorenyl)-2-( $p$-trimethylsilyl)phenylacetylene with $\mathrm{TaCl}_{5}-n-\mathrm{Bu}_{4} \mathrm{Sn}$ afforded a high molecular weight polymer, whose $\mathrm{PO}_{2}$ value was as high as 1700 barrers [6b]. Quite recently we have found that indan-containing poly(diarylacetylene)s exhibit gas permeability comparable to that of poly(TMSP) [7]. Polymers containing fluorene moieties in the main chain or side chain have attracted much attention as potential materials for light-emitting diodes [8], thin film transistors [9], solar cells [10], and gas separation membranes [11]. The 9-position of fluorene can be easily substituted by various groups. Thus, it is interesting to synthesize polyacetylenes having substituted fluorenyl groups in the side chain and to study their gas permeation properties.

Here we report the polymerization of diarylacetylenes containing substituted fluorenyl groups (Scheme 1, 1a-l), and the fabrication of free-standing membranes from resultant polymers $(\mathbf{2 a}-\mathbf{l})$. Furthermore, the gas permeability and general properties of polymers $\mathbf{2 a - 1}$ were investigated.

(insert Scheme 1 here)

\section{Experimental section}

\subsection{Measurements}

Molecular weights of polymers were estimated by gel permeation chromatography $\left(\mathrm{CHCl}_{3}\right.$ as eluent, polystyrene calibration). IR spectra were recorded on a JASCO FT/IR-4100 
spectrophotometer. ${ }^{1} \mathrm{H}(400 \mathrm{MHz})$ and ${ }^{13} \mathrm{C}(100 \mathrm{MHz})$ NMR spectra were observed in $\mathrm{CDCl}_{3}$ on a JEOL EX-400 spectrometer using tetramethylsilane as an internal standard. Elemental analysis of monomers was carried out at the Microanalytical Center of Kyoto University. Thermal gravimetric analysis (TGA) was conducted in air with a Shimadzu TGA-50 thermal analyzer. Melting points (mp) were determined on a Yanaco micro melting point apparatus.

\subsection{Materials}

$\mathrm{TaCl}_{5}$ (Aldrich) as main catalyst component was used without further purification. $n$ - $\mathrm{Bu}_{4} \mathrm{Sn}$ (Wako Pure Chemical) as cocatalyst was used after distillation. 4-(Trimethylsilyl)phenylacetylene was donated by NOF Co. Ltd. Fluorene, 2-bromofluorene, and 2,7-dibromofluorene were purchased from Aldrich. 4-tert-Butylphenylacetylene was commercially obtained from Wako Pure Chemical. Toluene as a polymerization solvent was purified by the standard method.

\subsection{Monomer synthesis}

$$
\text { 9,9-Dimethyl-2-iodofluorene, }
$$

1-(9,9-dimethylfluoren-2-yl)acetylene were prepared according to the literature method [12]. 2'-Bromo-spiro(cyclopropane-1,9'-fluorene) was prepared according to the literature procedure [13]. Monomers 1a-l were synthesized according to Scheme 2, referring to the literature with respect to the incorporation of the triple bond [14].

(insert Scheme 2 here) 


\subsubsection{1-Phenyl-2-(9,9-dimethylfluoren-2-yl)acetylene (1a)}

A $500 \mathrm{~mL}$ three-necked flask was equipped with a dropping funnel, a three-way stopcock, and a magnetic stirring bar, and was flushed with dry nitrogen. 9,9-Dimethyl-2-iodofluorene ( $8.0 \mathrm{~g}, 25 \mathrm{mmol})$, bis(triphenylphosphine)palladium dichloride $(0.18 \mathrm{~g}, 0.25 \mathrm{mmol})$, cuprous iodide $(0.29 \mathrm{~g}, 1.5 \mathrm{mmol})$, triphenylphosphine $(0.26 \mathrm{~g}, 1.0$ $\mathrm{mmol})$, and triethylamine $(200 \mathrm{~mL})$ were placed in the flask. Then, phenylacetylene $(3.2 \mathrm{~g}, 31$ mmol) in triethylamine $(15 \mathrm{~mL})$ solution was added dropwise, and the reaction mixture was stirred overnight at room temperature. After the triethylamine in the reaction mixture was evaporated, ether (ca. $300 \mathrm{~mL}$ ) was added, and then the insoluble salt was filtered off. The filtrate was washed with $1 \mathrm{M}$ hydrochloric acid and then with water. The ethereal solution was dried over anhydrous magnesium sulfate and then concentrated at reduced pressure. Purification of the crude product by silica gel column chromatography (eluent: hexane) provided the desired product. Yield $63 \%$, white solid; mp $129.0-130.0{ }^{\circ} \mathrm{C}$; IR $\left(\mathrm{KBr}, \mathrm{cm}^{-1}\right)$ : 2976, 2220, 1492, 1443, 1273, 1071, 882, 839, 756, 737, 692, 570. ${ }^{1} \mathrm{H}$ NMR $\left(\mathrm{CDCl}_{3}, \mathrm{ppm}\right)$ : 7.72-7.68 (m, 2H, Ar), 7.61 (s, 1H, Ar), 7.57-7.51 (m, 3H, Ar), 7.45-7.43 (m, 1H, Ar), 7.38-7.31 (m, 5H, Ar), $1.50\left(\mathrm{~s}, 6 \mathrm{H}, \mathrm{C}\left(\mathrm{CH}_{3}\right)_{2}\right) .{ }^{13} \mathrm{C} \mathrm{NMR}\left(\mathrm{CDCl}_{3}, \mathrm{ppm}\right): 153.9,153.6,139.4$, $138.5,131.6,130.7,128.3,128.1,127.7,127.1,125.9,123.4,122.6,121.7,120.3,119.9,90.2$, 89.4, 46.8, 27.0. Anal. Calcd for $\mathrm{C}_{23} \mathrm{H}_{18}$ : C, 93.84; H, 6.16. Found: C, 93.55; H, 6.33.

\subsubsection{1-(4-Fluorophenyl)-2-(9,9-dimethylfluoren-2-yl)acetylene (1b)}

This monomer was prepared by the same method as for 1a by using $p$-fluoroiodobenzene and 1-(9,9-dimethylfluoren-2-yl)acetylene instead of 
9,9-dimethyl-2-iodofluorene and phenylacetylene to give a white solid; yield $84 \%$, mp 147.0-148.5 ${ }^{\circ} \mathrm{C} . \mathrm{IR}\left(\mathrm{KBr}, \mathrm{cm}^{-1}\right): 2962,2220,1895,1596,1506,1216,1156,1090,835,734$. ${ }^{1} \mathrm{H}$ NMR (CDCl 3 ,ppm): 7.72-7.67 (m, 2H, Ar), 7.59-7.43 (m, 5H, Ar), 7.36-7.32 (m, 2H, Ar),

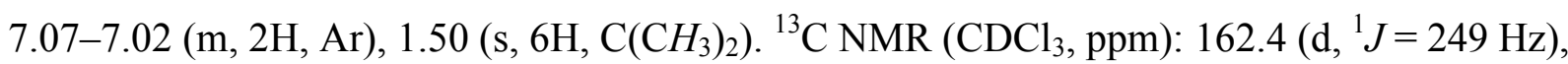
$153.9,153.6,139.5,138.4,133.4\left(\mathrm{~d},{ }^{3} J=9.10 \mathrm{~Hz}\right), 130.7,127.7,127.1,125.8,122.6,121.5$, 120.3, 120.0, $119.5\left(\mathrm{~d},{ }^{4} J=3.30 \mathrm{~Hz}\right), 115.6\left(\mathrm{~d},{ }^{2} J=22.3 \mathrm{~Hz}\right), 89.9,88.3,46.8,27.0$. Anal. Calcd for $\mathrm{C}_{23} \mathrm{H}_{17} \mathrm{~F}: \mathrm{C}, 88.43$; H, 5.49. Found: C, 88.39; H, 5.60.

\subsubsection{1-(3-Fluorophenyl)-2-(9,9-dimethylfluoren-2-yl)acetylene (1c)}

This monomer was prepared by the same method as for $\mathbf{1 b}$ by using $m$-fluoroiodobenzene instead of $p$-fluoroiodobenzene to give a white solid; yield $88 \%$, mp 87.0-88.0 ${ }^{\circ} \mathrm{C}$. IR $\left(\mathrm{KBr}, \mathrm{cm}^{-1}\right): 2979,2206,1912,1577,1449,1192,860,781,735,678 .{ }^{1} \mathrm{H}$ NMR ( $\left.\mathrm{CDCl}_{3}, \mathrm{ppm}\right):$ 7.73-7.69 (m, 2H, Ar), 7.60 (s, 1H, Ar), 7.52 (d, J=7.9 Hz, 1H, Ar), $7.44(\mathrm{~m}, 1 \mathrm{H}, \mathrm{Ar}), 7.35-7.24(\mathrm{~m}, 5 \mathrm{H}, \mathrm{Ar}), 7.04(\mathrm{~m}, 1 \mathrm{H}, \mathrm{Ar}), 1.50\left(\mathrm{~s}, 6 \mathrm{H}, \mathrm{C}\left(\mathrm{CH}_{3}\right)_{2}\right) .{ }^{13} \mathrm{C} \mathrm{NMR}$ $\left(\mathrm{CDCl}_{3}, \mathrm{ppm}\right): 162.4\left(\mathrm{~d},{ }^{1} J=246 \mathrm{~Hz}\right), 153.9,153.6,139.8,138.4,130.8,129.9\left(\mathrm{~d},{ }^{3} J=9.10\right.$ $\mathrm{Hz}), 127.8,127.4\left(\mathrm{~d},{ }^{4} J=3.30 \mathrm{~Hz}\right), 127.1,126.0,125.3\left(\mathrm{~d},{ }^{3} J=9.09 \mathrm{~Hz}\right), 122.6,121.1,120.3$, 120.0, $118.3\left(\mathrm{~d},{ }^{2} J=23.1 \mathrm{~Hz}\right), 115.4\left(\mathrm{~d},{ }^{2} J=20.7 \mathrm{~Hz}\right), 91.2,88.2\left(\mathrm{~d},{ }^{4} J=3.30 \mathrm{~Hz}\right), 46.8,27.0$. Anal. Calcd for $\mathrm{C}_{23} \mathrm{H}_{17} \mathrm{~F}$ : C, 88.43; H, 5.49. Found: C, 88.50; H, 5.75.

\subsubsection{1-(3,4-Difluorophenyl)-2-(9,9-dimethylfluoren-2-yl)acetylene (1d)}

This monomer was prepared by the same method as for $\mathbf{1 b}$ by using 1-iodo-3,4-difluorobenzene instead of $p$-fluoroiodobenzene to give a white solid; yield $88 \%$, mp 105.0-106.5 ${ }^{\circ} \mathrm{C} . \mathrm{IR}\left(\mathrm{KBr}, \mathrm{cm}^{-1}\right): 2975,2210,1913,1597,1517,1273,1116,860,759,735$. 
${ }^{1} \mathrm{H} \mathrm{NMR}\left(\mathrm{CDCl}_{3}, \mathrm{ppm}\right):$ 7.73-7.69 (m, 2H, Ar), 7.59 (s, 1H, Ar), 7.50 (d, J=8.0 Hz, 1H, Ar), 7.44 (m, 1H, Ar), 7.38-7.25 (m, 4H, Ar), 7.14 (m, 1H, Ar), $1.50\left(\mathrm{~s}, 6 \mathrm{H}, \mathrm{C}\left(\mathrm{CH}_{3}\right)_{2}\right) .{ }^{13} \mathrm{C} \mathrm{NMR}$ $\left(\mathrm{CDCl}_{3}, \mathrm{ppm}\right): 153.9,153.6,150.4\left(\mathrm{dd},{ }^{1} J=251 \mathrm{~Hz},{ }^{2} J=12.4 \mathrm{~Hz}\right), 150.0\left(\mathrm{dd},{ }^{1} J=248 \mathrm{~Hz},{ }^{2} J\right.$ $=12.4 \mathrm{~Hz}), 139.8,138.3,130.7,128.1\left(\mathrm{dd},{ }^{3} J=6.20 \mathrm{~Hz},{ }^{4} J=3.73 \mathrm{~Hz}\right), 127.8,127.1,125.9$, 122.6, 120.9, $120.4\left(\mathrm{~d},{ }^{2} J=18.2 \mathrm{~Hz}\right), 120.3\left(\mathrm{~d},{ }^{3} J=8.26 \mathrm{~Hz}\right), 120.3,120.0,117.4\left(\mathrm{~d},{ }^{2} J=19.0\right.$ $\mathrm{Hz}), 90.8\left(\mathrm{~d},{ }^{5} J=2.48 \mathrm{~Hz}\right), 87.2(\mathrm{vt}, J=2.07 \mathrm{~Hz}), 46.8,26.9$. Anal. Calcd for $\mathrm{C}_{23} \mathrm{H}_{16} \mathrm{~F}_{2}: \mathrm{C}$, 83.62; H, 4.88. Found: C, 83.73; H, 5.12.

\subsubsection{1-(3,5-Difluorophenyl)-2-(9,9-dimethylfluoren-2-yl)acetylene (1e)}

This monomer was prepared by the same method as for $\mathbf{1 b}$ by using 1-iodo-3,5-difluorobenzene instead of $p$-fluoroiodobenzene to give a white solid; yield $79 \%$, mp 95.0-96.0 ${ }^{\circ} \mathrm{C} . \mathrm{IR}\left(\mathrm{KBr}, \mathrm{cm}^{-1}\right): 2979,2208,1912,1617,1424,1122,989,838,736,509$. ${ }^{1} \mathrm{H}$ NMR (CDCl 3 ,ppm): 7.71-7.66 (m, 2H, Ar), 7.59 (s, 1H, Ar), 7.49 (d, J=7.8 Hz, 1H, Ar), 7.43-7.41 (m, 1H, Ar), 7.35-7.31 (m, 2H, Ar), 7.06-7.04 (m, 2H, Ar), 6.80-6.75 (m, 1H, Ar), $1.48\left(\mathrm{~s}, 6 \mathrm{H}, \mathrm{C}\left(\mathrm{CH}_{3}\right)_{2}\right) .{ }^{13} \mathrm{C} \mathrm{NMR}\left(\mathrm{CDCl}_{3}, \mathrm{ppm}\right): 162.7\left(\mathrm{dd},{ }^{1} \mathrm{~J}=249 \mathrm{~Hz},{ }^{3} \mathrm{~J}=13.2 \mathrm{~Hz}\right), 153.9$, 153.7, 140.1, 138.3, 130.9, 127.9, 127.2, $126.2\left(\mathrm{t},{ }^{3} J=12.4 \mathrm{~Hz}\right), 126.0,122.7,120.6,120.4$, 120.0, $114.4\left(\mathrm{dd},{ }^{2} J=19.8 \mathrm{~Hz},{ }^{4} J=7.44 \mathrm{~Hz}\right), 104.2\left(\mathrm{t},{ }^{2} J=24.8 \mathrm{~Hz}\right), 92.3,87.2\left(\mathrm{t},{ }^{4} J=3.30\right.$ $\mathrm{Hz}$, 46.9, 27.0. Anal. Calcd for $\mathrm{C}_{23} \mathrm{H}_{16} \mathrm{~F}_{2}$ : C, 83.62; H, 4.88. Found: C, 83.59; H, 5.02.

\subsubsection{1-(4-Bromophenyl)-2-(9,9-dimethylfluoren-2-yl)acetylene (1f)}

This monomer was prepared by the same method as for $\mathbf{1 b}$ by using $p$-bromoiodobenzene instead of $p$-fluoroiodobenzene to give a white solid; yield $77 \%, \mathrm{mp}$ 145.0-147.0 ${ }^{\circ} \mathrm{C}$. IR $\left(\mathrm{KBr}, \mathrm{cm}^{-1}\right): 2958,2220,1905,1490,1066,1009,887,735,523 .{ }^{1} \mathrm{H}$ 
NMR ( $\left.\mathrm{CDCl}_{3}, \mathrm{ppm}\right)$ : 7.73-7.68 (m, 2H, Ar), 7.59 (s, 1H, Ar), 7.51-7.47 (m, 3H, Ar), 7.45-7.39 (m, 3H, Ar), 7.37-7.31 (m, 2H, Ar), $1.49\left(\mathrm{~s}, 6 \mathrm{H}, \mathrm{C}\left(\mathrm{CH}_{3}\right)_{2}\right) .{ }^{13} \mathrm{C} \mathrm{NMR}\left(\mathrm{CDCl}_{3}\right.$, ppm): 153.9, 153.6, 139.7, 138.4, 133.0, 131.6, 130.7, 127.8, 127.1, 125.9, 122.7, 122.4, 122.3, 121.3, 120.3, 120.0, 91.4, 88.4, 46.9, 27.0. Anal. Calcd for $\mathrm{C}_{23} \mathrm{H}_{17} \mathrm{Br}: \mathrm{C}, 74.00 ; \mathrm{H}, 4.59$. Found: C, 74.12; H, 4.89 .

\subsubsection{1-(4-tert-Butylphenyl)-2-(9,9-dimethylfluoren-2-yl)acetylene (1g)}

This monomer was prepared by the same method as for 1a by using 4-tert-butylphenylacetylene instead of phenylacetylene to give a white solid; yield $35 \%$, mp 177.5-179.5 ${ }^{\circ} \mathrm{C} . \mathrm{IR}\left(\mathrm{KBr}, \mathrm{cm}^{-1}\right): 2959,1506,1445,1396,834,782,757,736,567 .{ }^{1} \mathrm{H}$ NMR $\left(\mathrm{CDCl}_{3}, \mathrm{ppm}\right):$ 7.72-7.67 (m, 2H, Ar), 7.60 (s, 1H, Ar), 7.52-7.48 (m, 3H, Ar), 7.44-7.42 (m, 1H, Ar), 7.39-7.31 (m, 4H, Ar), $1.50\left(\mathrm{~s}, 6 \mathrm{H}, \mathrm{C}\left(\mathrm{CH}_{3}\right)_{2}\right), 1.33\left(\mathrm{~s}, 9 \mathrm{H}, \mathrm{C}\left(\mathrm{CH}_{3}\right)_{3}\right) .{ }^{13} \mathrm{C} \mathrm{NMR}$ $\left(\mathrm{CDCl}_{3}, \mathrm{ppm}\right): 153.9,153.6,151.4,139.2,138.6,131.3,130.7,127.6,127.1,125.9,125.4$, 122.6, 121.9, 120.4, 120.2, 119.9, 89.6, 89.6, 46.8, 34.8, 31.2, 27.0. Anal. Calcd for $\mathrm{C}_{27} \mathrm{H}_{26}$ : C, 92.52; H, 7.48. Found: C, 92.24; H, 7.54.

\subsubsection{1-(4-Trimethylsilylphenyl)-2-(9,9-dimethylfluoren-2-yl)acetylene (1h)}

This monomer was prepared by the same method as for 1a by using 4-(trimethylsilyl)phenylacetylene instead of phenylacetylene to give a white solid; yield 63\%, mp 139.0-142.0 ${ }^{\circ} \mathrm{C} . \mathrm{IR}\left(\mathrm{KBr}, \mathrm{cm}^{-1}\right):$ 2959, 2219, 1591, 1445, 1252, 1099, 824, 757, 633, 454. ${ }^{1} \mathrm{H}$ NMR $\left(\mathrm{CDCl}_{3}, \mathrm{ppm}\right)$ : 7.73-7.68 (m, 2H, Ar), 7.61 (s, 1H, Ar), 7.54-7.49 (m, 5H, Ar), 7.45-7.43 (m, 1H, Ar), 7.36-7.31 (m, 2H, Ar), $1.50\left(\mathrm{~s}, 6 \mathrm{H}, \mathrm{C}\left(\mathrm{CH}_{3}\right)_{2}\right), 0.28\left(\mathrm{~s}, 9 \mathrm{H}, \mathrm{Si}\left(\mathrm{CH}_{3}\right)_{3}\right)$.

${ }^{13} \mathrm{C}$ NMR $\left(\mathrm{CDCl}_{3}, \mathrm{ppm}\right): 153.9,153.6,140.9,139.4,138.5,133.2,130.8,130.6,127.7,127.1$, 
$125.9,123.7,122.7,121.7,120.3,119.9,90.6,89.6,46.9,27.0,-1.2$. Anal. Calcd for $\mathrm{C}_{26} \mathrm{H}_{26} \mathrm{Si}: \mathrm{C}, 85.19 ; \mathrm{H}, 7.15$. Found: C, 85.05; H, 7.24.

\subsubsection{1-Phenyl-2-(9,9-dimethyl-7-bromofluoren-2-yl)acetylene (1i)}

This monomer was prepared similarly to 1a from 9,9-dimethyl-2,7-dibromofluorene to give a white solid; yield $37 \%$, mp $149.5-150.5{ }^{\circ} \mathrm{C}$. IR $\left(\mathrm{KBr}, \mathrm{cm}^{-1}\right): 2978,1442,1400,1257$, 1073, 820, 751, 686, 466. ${ }^{1} \mathrm{H}$ NMR ( $\left.\mathrm{CDCl}_{3}, \mathrm{ppm}\right): 7.65$ (d, $\left.J=7.8 \mathrm{~Hz}, 1 \mathrm{H}, \mathrm{Ar}\right), 7.59-7.51$ (m, 6H, Ar), $7.46(\mathrm{~d}, J=8.0 \mathrm{~Hz}, 1 \mathrm{H}, \mathrm{Ar}), 7.39-7.33(\mathrm{~m}, 3 \mathrm{H}, \mathrm{Ar}), 1.49\left(\mathrm{~s}, 6 \mathrm{H}, \mathrm{C}\left(\mathrm{C} \mathrm{H}_{3}\right)_{2}\right) .{ }^{13} \mathrm{C} \mathrm{NMR}$ $\left(\mathrm{CDCl}_{3}, \mathrm{ppm}\right): 155.9,153.2,138.3,137.5,131.6,130.9,130.3,128.4,128.3,126.2,125.9$ 123.3, 122.2, 121.6, 121.5, 120.0, 90.0, 89.8, 47.1, 26.9. Anal. Calcd for $\mathrm{C}_{23} \mathrm{H}_{17} \mathrm{Br}: \mathrm{C}, 74.00$; H, 4.59. Found: C, 74.00; H, 4.67.

\subsubsection{1-Phenyl-2-(9,9-dimethyl-7-trimethylsilylfluoren-2-yl)acetylene (1j)}

A $300 \mathrm{~mL}$ three-necked flask was equipped with a dropping funnel, a three-way stopcock, and a magnetic stirring bar. After the flask was flushed with nitrogen, 9,9-dimethyl-2,7-dibromofluorene (10 g, $28 \mathrm{mmol})$, ether $(100 \mathrm{~mL})$, and benzene $(40 \mathrm{~mL})$ were added and cooled at $0{ }^{\circ} \mathrm{C}$. At the same temperature, a hexane solution of $n$-butyllithium (18 $\mathrm{mL}, 1.6 \mathrm{M}, 28 \mathrm{mmol}$ ) was added dropwise, and then the mixture was stirred for $2 \mathrm{~h}$ at room temperature. Then, a solution of trimethylchlorosilane $(3.0 \mathrm{~g}, 28 \mathrm{mmol})$ in ether (10 $\mathrm{mL}$ ) was added dropwise at $0{ }^{\circ} \mathrm{C}$, and stirring was continued further for $5 \mathrm{~h}$ at room temperature. A small amount of water was added at $0{ }^{\circ} \mathrm{C}$, and the reaction mixture was extracted with ether. The organic phase was washed with water, and dried over anhydrous magnesium sulfate. After ether was evaporated, the crude product was purified by silica gel 
column chromatography hexane) to give

9,9-dimethyl-2-bromo-7-(trimethylsilyl)fluorene as a white solid.

1j was prepared similarly to $\mathbf{1 a}$ by using 9,9-dimethyl-2-bromo-7-(trimethylsilyl)fluorene instead of 9,9-dimethyl-2-iodofluorene to give a white solid; yield $43 \%$, mp $124.0-125.0^{\circ} \mathrm{C}$. IR $\left(\mathrm{KBr}, \mathrm{cm}^{-1}\right): 2958,1458,1396,1246$, 1107, 825, 756, 690, 629, 462. ${ }^{1} \mathrm{H} \mathrm{NMR}\left(\mathrm{CDCl}_{3}, \mathrm{ppm}\right): 7.70$ (d, $\left.J=7.3 \mathrm{~Hz}, 2 \mathrm{H}, \mathrm{Ar}\right)$, 7.60-7.50 (m, 6H, Ar), 7.37-7.34 (m, 3H, Ar), $1.51\left(\mathrm{~s}, 6 \mathrm{H}, \mathrm{C}\left(\mathrm{CH}_{3}\right)_{2}\right), 0.32\left(\mathrm{~s}, 9 \mathrm{H}, \mathrm{Si}\left(\mathrm{CH}_{3}\right)_{3}\right)$. ${ }^{13} \mathrm{C} \mathrm{NMR}\left(\mathrm{CDCl}_{3}, \mathrm{ppm}\right): 153.8,153.0,140.1,139.4,139.2,132.2,131.6,130.7,128.4,128.1$, 127.2, 125.9, 123.4, 121.8, 120.1, 119.6, 90.3, 89.5, 46.9, 27.1, -0.9. Anal. Calcd for $\mathrm{C}_{26} \mathrm{H}_{26} \mathrm{Si}: \mathrm{C}, 85.19 ; \mathrm{H}, 7.15$. Found: C, 85.41; H, 7.25.

\subsubsection{1-Phenyl-2-(spiro[cyclopropane-1,9'-fluoren]-2'-yl)acetylene (1k)}

This monomer was prepared similarly to $\mathbf{1 a}$ from 2'-bromo-spiro(cyclopropane-1,9'-fluorene) to give a white solid; yield $72 \%$, mp 103.5-105.0 ${ }^{\circ} \mathrm{C} . \mathrm{IR}\left(\mathrm{KBr}, \mathrm{cm}^{-1}\right): 3053,3004,2207,1490,1439,1426,951,835,745,691,473$. ${ }^{1} \mathrm{H} \mathrm{NMR}\left(\mathrm{CDCl}_{3}, \mathrm{ppm}\right):$ 7.81-7.76 (m, 2H, Ar), 7.55-7.51 (m, 3H, Ar), 7.36-7.27 (m, 5H, Ar), $7.21(\mathrm{~s}, 1 \mathrm{H}, \mathrm{Ar}), 7.03(\mathrm{~d}, J=7.5 \mathrm{~Hz}, 1 \mathrm{H}, \mathrm{Ar}), 1.76-1.69\left(\mathrm{~m}, 4 \mathrm{H}, \mathrm{CCH}_{2} \mathrm{CH}_{2}\right) .{ }^{13} \mathrm{C}$ NMR $\left(\mathrm{CDCl}_{3}, \mathrm{ppm}\right): 148.5,148.2,140.0,139.2,131.5,129.7,128.3,128.1,127.2,126.1,123.4$ 121.8, 121.2, 120.3, 119.9, 118.6, 90.3, 89.4, 29.4, 18.4. Anal. Calcd for $\mathrm{C}_{23} \mathrm{H}_{16}$ : C, 94.48; $\mathrm{H}$, 5.52. Found: C, 94.52; H, 5.63.

2.3.12. 1-(4-Trimethylsilylphenyl)-2-(spiro[cyclopropane-1,9'-fluoren]-2'-yl)acetylene (11)

This monomer was prepared by the same method as for $\mathbf{1 k}$ by using 
4-(trimethylsilyl)phenylacetylene instead of phenylacetylene to give a white solid; yield $61 \%$, mp 142.5-144.0 ${ }^{\circ} \mathrm{C}$. IR $\left(\mathrm{KBr}, \mathrm{cm}^{-1}\right): 2954,1592,1426,1250,1098,953,841,820,752,632$. ${ }^{1} \mathrm{H} \mathrm{NMR}\left(\mathrm{CDCl}_{3}, \mathrm{ppm}\right):$ 7.81-7.76 (m, 2H, Ar), 7.53-7.48 (m, 5H, Ar), 7.36-7.27 (m, 2H, Ar), $7.22(\mathrm{~s}, 1 \mathrm{H}, \mathrm{Ar}), 7.03(\mathrm{~d}, J=7.3 \mathrm{~Hz}, 1 \mathrm{H}, \mathrm{Ar}), 1.77-1.69\left(\mathrm{~m}, 4 \mathrm{H}, \mathrm{CCH}_{2} \mathrm{CH}_{2}\right), 0.27(\mathrm{~s}, 9 \mathrm{H}$, $\left.\mathrm{Si}\left(\mathrm{CH}_{3}\right)_{3}\right) .{ }^{13} \mathrm{C} \mathrm{NMR}\left(\mathrm{CDCl}_{3}, \mathrm{ppm}\right): 148.5,148.2,140.9,140.0,139.2,133.2,130.6,129.7$, 127.2, 126.1, 123.7, 121.9, 121.3, 120.3, 119.9, 118.6, 90.7, 89.6, 29.4, 18.4, -1.2. Anal. Calcd for $\mathrm{C}_{26} \mathrm{H}_{24} \mathrm{Si}: \mathrm{C}, 85.66 ; \mathrm{H}, 6.64$; $\mathrm{Si}, 7.70$. Found: C, 85.70; H, 6.79.

\subsection{Polymerization}

Polymerizations were performed in a Schlenk tube equipped with a three-way stopcock under dry nitrogen. The polymerizations were carried out at $80{ }^{\circ} \mathrm{C}$ for $24 \mathrm{~h}$ under the following conditions: $[\mathrm{M}]_{0}=0.20 \mathrm{M},\left[\mathrm{TaCl}_{5}\right]=20 \mathrm{mM},\left[n-\mathrm{Bu}_{4} \mathrm{Sn}\right]=40 \mathrm{mM}$. A detailed procedure of polymerization was as follows: a monomer solution was prepared in a Schlenk tube by mixing monomer $1 \mathrm{a}(0.30 \mathrm{~g})$ and toluene $(3.0 \mathrm{~mL})$. Another Schlenk tube was charged with $\mathrm{TaCl}_{5}(36 \mathrm{mg}), n-\mathrm{Bu}_{4} \mathrm{Sn}(0.066 \mathrm{~mL})$, and toluene $(2.0 \mathrm{~mL})$; this catalyst solution was aged at $80^{\circ} \mathrm{C}$ for $10 \mathrm{~min}$. Then the monomer solution was added to the catalyst solution. Polymerization was carried out at $80^{\circ} \mathrm{C}$ for $24 \mathrm{~h}$, which was quenched with a small amount of methanol. The formed polymers were isolated by precipitation into a large amount of methanol, and dried to constant weight; the polymer yields were determined by gravimetry.

\subsection{Membrane fabrication}


Membranes (thickness ca. $50-80 \mu \mathrm{m}$ ) were fabricated by casting from toluene solution (2a-e, $2 \mathbf{g}, \mathbf{2 h}$, and $\mathbf{2} \mathbf{j}-\mathbf{l})$ and chloroform solution ( $2 \mathbf{f}$ and $\mathbf{2 i})$ due to the difference in their solubility onto a flat-bottomed Petri dish (concentration ca. $0.80-1.5 \mathrm{wt} \%$ ). Then, the dish was covered with a glass vessel to retard the rate of solvent evaporation (ca. 3-5 days). After membranes were prepared, they were immersed in methanol for $24 \mathrm{~h}$ and dried to constant weight at room temperature for $24 \mathrm{~h}$.

\subsection{Measurement of gas permeabilities}

Gas permeability coefficients of polymer membranes were measured with a Rikaseiki K-315-N gas permeability apparatus equipped with an MKS Baratron detector at $25{ }^{\circ} \mathrm{C}$. The downstream side of the membrane was evacuated at $0.3 \mathrm{~Pa}$, while the upstream side was filled with a gas at about 1 atm $\left(10^{5} \mathrm{~Pa}\right)$, and the increase of pressure in a downstream receiving vessel was measured. $P$ values were calculated from the slopes of time-pressure curves in the steady state where Fick's law held.

\section{Results and discussion}

\subsection{Polymerization}

The polymerization of monomers $1 \mathbf{a}-\mathbf{l}$ having fluorenyl groups was carried out in toluene by using the $\mathrm{TaCl}_{5}-n-\mathrm{Bu}_{4} \mathrm{Sn}$ catalyst (Table 1). It is well known that the $\mathrm{TaCl}_{5}-n-\mathrm{Bu}_{4} \mathrm{Sn}$ catalyst is effective for the polymerization of diphenylacetylene derivatives, 
and provides polymers having high molecular weight [15], which is essential for the fabrication of free-standing membranes. Monomer 1a afforded a polymer in a moderate yield $(42 \%)$, whose $M_{\mathrm{w}}$ was as high as $5.9 \times 10^{5}$. Similarly, fluorine-containing monomers $\mathbf{1 b}-\mathbf{e}$ polymerized in ca. $40-60 \%$ yields into high molecular weight polymers $\left(M_{\mathrm{w}} \geq 5.3 \times 10^{5}\right)$. Monomers 1f-j having bulky substituents also gave high molecular weight polymers. For instance, bromine-containing monomers 1 f and 1i produced polymers with high $M_{\mathrm{w}}$ values $\left(5.5 \times 10^{5}\right.$ and $5.7 \times 10^{5}$, respectively) in $43 \%$ yield. Monomer $1 \mathrm{~g}$ having a $t$-butyl group produced a polymer with $M_{\mathrm{w}}\left(7.9 \times 10^{5}\right)$ in a low yield $(14 \%)$. Monomers $\mathbf{1 h}$ and $\mathbf{1 j}$ possessing a bulky trimethylsilyl group afforded polymers, whose $M_{\mathrm{w}}$ values reached $5.1 \times$ $10^{5}$ and $5.8 \times 10^{5}$, respectively, although the polymer yields were rather low (12 and 25\%). Monomers $1 \mathbf{k}$ and $\mathbf{1 l}$ possessing a cyclopropane moiety at the C-9 position of fluorene polymerized practically in the same way as $\mathbf{1 a}$. Thus, all of polymers $\mathbf{2} \mathbf{a}-\mathbf{I}$ possessed enough high molecular weights for the fabrication of free-standing membranes. The appearance of these polymers was orange-colored and fibrous.

(insert Table 1 here)

\subsection{Solubility and thermal stability of the polymers}

Solubility properties of polymers $\mathbf{2 a}-\mathbf{l}$ are summarized in Table 2. Polymers $\mathbf{2 a}-\mathbf{I}$ were all soluble in $\mathrm{CHCl}_{3}$ and THF, and most of them were also soluble in toluene. The polymers having trimethylsilyl and $t$-butyl groups dissolved also in cyclohexane, while those with halogens tended to dissolve in $N, N$-dimethylformamide (DMF), a polar solvent. All the present polymers were insoluble in methanol. Due to the difference in their solubility, 
free-standing membranes were fabricated from either toluene $(\mathbf{2} \mathbf{a}-\mathbf{e}, \mathbf{2 g}, \mathbf{2 h}$, and $\mathbf{2} \mathbf{j}-\mathbf{l})$ or $\mathrm{CHCl}_{3}$ (2f and $\mathbf{2 i}$ ) solution. The formed membranes were sufficiently tough, stiff, red, and transparent.

(insert Table 2 here)

The thermal stability of polymers $\mathbf{2 a}-\mathbf{I}$ was examined by TGA in air (Fig. 1). The onset temperatures of weight loss $\left(T_{0}\right)$ of $\mathbf{2 a}-\mathbf{l}$ were all above $400{ }^{\circ} \mathrm{C}$, indicating considerably high thermal stability. When Si-containing polymers $\mathbf{2 h}, \mathbf{2} \mathbf{j}$, and $\mathbf{2 l}$ were heated above $700{ }^{\circ} \mathrm{C}$ in air, the ash composed of $\mathrm{SiO}_{2}$ remained, whose amounts agreed with the expected values.

(insert Fig. 1 here)

\subsection{Gas permeability}

The gas permeability of membranes $\mathbf{2 a}-\mathbf{l}$ to various gases was examined at $25{ }^{\circ} \mathrm{C}$ (Table 3). The oxygen permeability coefficient $\left(\mathrm{PO}_{2}\right)$ of $\mathbf{2 a}$ was as large as 4800 barrers. We previously synthesized poly[1-(2-fluorenyl)-2-( $p$-trimethylsilyl)phenylacetylene] without two methyl groups at 9-position of the fluorenyl group and its desilylated polymer 3m (Chart 1) [6b]. Their $\mathrm{PO}_{2}$ values were 1700 and 2200 barrers, respectively. These results indicate that the oxygen permeability is remarkably enhanced by introducing two methyl groups into polymer $\mathbf{2} \mathbf{m}$. The reason for the high gas permeability of $\mathbf{2 a}$ is probably that the two methyl groups, sticking out vertically from the rigid fluorene plane, inhibit the effective $\pi$-stacking between aromatic rings, generating a large amount of molecular-scale void in the membrane. Similar and even more obvious effects of plural numbers of methyl groups have been observed in our recent studies of poly(diarylacetylene)s having polymethylated indanyl 
groups [7], although a polymer having the 9,9,10,10-tetramethyl-9,10-dihydroanthracene moiety did not show so high gas permeability [16].

\section{(insert Chart 1 here)}

Fluorine-containing polymers tended to display even higher oxygen permeability; namely, the $\mathrm{PO}_{2}$ values of $\mathbf{2 b}-\mathbf{d}$ were clearly larger than that of $\mathbf{2 a}$, and $\mathbf{2 d}$ possessing two fluorine atoms at meta and para positions exhibited the highest permeability among the present polymers $\left(\mathrm{PO}_{2}=6600\right.$ barrers $)$. Thus, it can be said that incorporation of $\mathrm{F}$ atoms into poly(diarylacetylene)s is effective to enhance the gas permeability of the membranes [19]. The reason why polymer $\mathbf{2 e}$ showed lower permeability might be that the $m, m$-difluorophenyl group is more planar and tends to stack with one another.

Polymer $2 \mathbf{f}$ having bromine atoms also displayed high gas permeability $\left(\mathrm{PO}_{2}=5000\right.$ barrers), while $\mathbf{2 g}$ having $t$-butyl groups showed somewhat lower gas permeability $\left(\mathrm{PO}_{2}=\right.$ 3500 barrers). Furthermore, $\mathbf{2 h}$ having trimethylsilyl groups exhibited the lowest gas permeability within this series $\left(\mathrm{PO}_{2}=470\right.$ barrers $)$, which was only one tenth of that of $\mathbf{2 a}$. This implies that a bulkier spherical substituent rather lowers the gas permeability in this type of polymers.

Polymers having the same substituents at different positions showed different $\mathrm{PO}_{2}$ values. For example, the $\mathrm{PO}_{2}$ value of bromine-containing polymer $\mathbf{2 i}$ was 2000 barrers, which was much lower than that of $\mathbf{2} \mathbf{f}\left(\mathrm{PO}_{2}=5000\right.$ barrers $)$, while polymer $\mathbf{2} \mathbf{j}$ possessing trimethylsilyl groups exhibited much higher gas permeability $\left(\mathrm{PO}_{2}=5400\right.$ barrers $)$ than that of $\mathbf{2 h}\left(\mathrm{PO}_{2}=470\right.$ barrers $)$. Polymers $\mathbf{2 k}$ and $\mathbf{2 l}$ containing cyclopropane moiety showed rather low gas permeability; the $\mathrm{PO}_{2}$ values of $2 \mathbf{k}$ and $2 \mathrm{I}$ remained 660 and 1000 barrers, respectively. The gas permeability difference between $\mathbf{2 a}$ and $\mathbf{2} \mathbf{k}$ suggests that the rotational motion of 
methyl groups plays an important role to enhance gas permeability, which agrees with the results of dynamic neutron scattering [20]. The permeability of $\mathbf{2 a - 1}$ to other gases such as $\mathrm{He}$, $\mathrm{H}_{2}, \mathrm{~N}_{2}, \mathrm{CO}_{2}$, and $\mathrm{CH}_{4}$ showed similar tendencies. The separation factors of oxygen against nitrogen $\left(\mathrm{PO}_{2} / \mathrm{PN}_{2}\right)$ of polymers $\mathbf{2 a}-\mathbf{l}$ were in a range of 1.3-2.2, where a tradeoff is observed between permeability and permselectivity, namely, more permeable polymers are generally less selective and vice versa [21].

(insert Table 3 here)

The time dependence of oxygen permeability of 2a (thickness: ca. $80 \mu \mathrm{m}$ ) was examined by storing the membrane at $25{ }^{\circ} \mathrm{C}$ in air. As seen in Fig. 2, the $P_{\mathrm{O}_{2}}$ value of $\mathbf{2 a}$ gradually decreased with time to become a half of the initial value after 60 days, and it decreased further to 2000 barrers after 90 days and almost leveled off. On the other hand, the $\mathrm{PO}_{2} / \mathrm{PN}_{2}$ value of $2 \mathrm{a}$ gradually increased from 1.43 to 1.84 after 90 days. Similar tendencies have been observed with other disubstituted acetylene polymers. For instance, the $\mathrm{PO}_{2}$ value of poly(TMSP) decreases from ca. 5000 to ca. 100 barrers after about 100 days [22], and that of poly[1- $\beta$-naphthyl-2-( $p$-trimethylsilyl)phenylacetylene] decreases from 3500 to 1000 barrers after 90 days [6c]. The decreased $\mathrm{PO}_{2}$ value of $\mathbf{2 a}$ was completely restored to the initial value when the membrane was immersed in methanol for $24 \mathrm{~h}$.

(insert Fig. 2 here)

\section{Conclusions}

A series of poly(diarylacetylene)s having fluorenyl groups (2a-l) were synthesized by the polymerization of the corresponding monomers. These polymers possessed high 
molecular weight, good solubility in organic solvents, and high thermal stability. All of the polymers gave free-standing membranes by solution casting, and exhibited high gas permeability. The $\mathrm{PO}_{2}$ value of polymer 2a was 4800 barrers, which is three times as large as that of poly(TMSDPA). Further, polymers containing both fluorenyl groups and fluorine atoms showed even larger oxygen permeability, and the value of $\mathbf{2 d}$ reached 6600 barrers. The results in the present study indicate that the incorporation of both 9,9-dimethylfluorenyl groups and fluorine atoms achieves high gas permeability. These polymer membranes are thought to be promising candidates for gas separation membranes from the viewpoint of high gas permeability and high thermal stability.

\section{Acknowledgments}

This research was supported by a grant-in-aid for scientific research from the Ministry of Education, Science, Culture, and Sports (Japan). We thank NOF Corp. for the donation of 4-(trimethylsilyl)phenylacetylene.

\section{References and Notes}

[1] (a) Masuda T, Shiotsuki M, Tabei J. Stereoselective Polymerization with Single-Site Catalysts. In: Baugh LS, Canich JAM, editors. Florida: CRC Press, 2008 (chapter 21).

(b) Masuda T, Sanda F, Shiotsuki M. Comprehensive Organometallic Chemistry III, 1st ed. In: Crabtree RH, Mingos DMP, editors. Oxford, UK: Elsevier, 2007 (chapter 11. 6. 1). 
(c) Mayershofer MG, Nuyken O. J Polym Sci Part A Polym Chem 2005;43:5723-5747.

(d) Lam JWY, Tang BZ. Acc Chem Res 2005;38:745-754.

(e) Sedlacek J, Vohlidal J. Collect Czech Chem Commun 2003;41:1745.

(f) Lam JWY, Tang BZ. J Polym Sci Part A Polym Chem 2003;41:2607-2629.

(g) Masuda T, Sanda F. Handbook of Metathesis. In: Grubbs RH, editor. Weinheim, Germany: Wiley-VCH, 2003 (chapter 3. 11).

(h) Choi SK, Gal YS, Jin SH, Kim HK. Chem Rev 2000;100:1645-1682.

(i) Tabata M, Sone T, Sadahiro Y. Macromol Chem Phys 1999;200:265-282.

[2] (a) Nagai K, Lee YM, Masuda T. Macromolecular Engineering. In: Matyjaszewsky K, Gnanou Y, Leibler L, editors. Weinheim, Germany: Wiley-VCH, 2007 (part 4, chapter 19).

(b) Masuda T, Nagai K. Materials Science of Membanes. In: Yampolskii Y, Pinnau I, Freeman BD, editors. Chichester, UK: Wiley, 2006 (chapter 8).

(c) Ulbricht M. Polymer 2006;47:2217-2262.

(d) Aoki T, Kaneko T, Teraguchi M. Polymer 2006;47:4867-4892.

(e) Sakaguchi T, Yumoto K, Shida Y, Shiotsuki M, Sanda F, Masuda T. J Polym Sci Part A Polym Chem 2006;44:5028-5038.

(f) Nagai K, Masuda T, Nakagawa T, Freeman BD, Pinnau I. Prog Polym Sci 2001;26:721-798.

[3] (a) Masuda T, Isobe E, Higashimura T, Takada K. J Am Chem Soc $1983 ; 105: 7473-7474$.

(b) Masuda T, Isobe E, Higashimura T. Macromolecules 1985;18:841-845.

[4] (a) Tsuchihara K, Masuda T, Higashimura T. J Am Chem Soc 1991;113:8548-8549. 
(b) Tsuchihara K, Masuda T, Higashimura T. Macromolecules 1992;25:5816-5820.

[5] Pauly S. Polymer Handbook, 4th ed. In: Brandrup J, Immergut EH, Grulke EA, editors. New York: John Wiley \& Sons 1999, p VI 558.

[6] (a) Sakaguchi T, Yumoto K, Shiotsuki M, Sanda F, Yoshikawa M, Masuda T. Macromolecules 2005;38:2704-2709.

(b) Sakaguchi T, Shiotsuki M, Masuda T. Macromolecules 2004;37:4104-4108.

(c) Sakaguchi T, Kwak G, Masuda T. Polymer 2002;43:3937-3942.

(d) Teraguchi M, Masuda, T. Macromolecules 2002;35:1149-1151.

[7] (a) Hu Y, Shiotsuki M, Sanda F, Freeman BD, Masuda T. Macromolecules $2008 ; 41: 8525-8532$.

(b) Hu Y, Shiotsuki M, Sanda F, Masuda T. Chem Commun 2007;4269-4270.

[8] (a) Haldi A, Kimyonok A, Domercq B, Hayden LE, Jones SC, Marder SR, Weck M, Kippelen B. Adv Funct Mater 2008;18:3056-3062.

(b) Yoon KJ, Park JS, Lee SJ, Song M, Shin IA, Lee JW, Gal YS, Jin SH. J Polym Sci Part A Polym Chem 2008;46:6762-6769.

(c) Jin Y, Song S, Kim JY, Kim H, Lee K, Suh H. Thin Solid Films 2008;516:7373-7380.

(d) Liu R, Xiong Y, Zeng W, Wu Z, Du B, Yang W, Sun M, Cao Y. Macromol Chem Phys 2007;208:1503-1509.

(e) Qiang P, Minggui X, Yan H, Zhiyun L, Dan X. J Polym Sci Part A Polym Chem 2004;42:2985-2993.

[9] (a) Kong H, Lee DH, Kang IN, Lim E, Jung YK, Park JH, Ahn T, Yi MH, Park CE, Shim HK. J Mater Chem 2008;18:1895-1902. 
(b) Lim E, Jung BJ, Chikamatsu M, Azumi R, Yoshida Y, Yase K, Do LM, Shim HK. J Mater Chem 2007; 17:1416-1420.

(c) Tian H, Wang J, Shi J, Yan D, Wang L, Geng Y, Wang F. J Mater Chem 2005; 15:3026-3033.

(d) Lim E, Jung BJ, Lee J, Shim HK, Lee JI, Yang YS, Do LM. Macromolecules $2005 ; 38: 4531-4535$.

(e) Salleo A, Street RA. J Appl Phys 2003;94:471-479.

[10] (a) Huang JH, Yang CY, Ho ZY, Kekuda D, Wu MC, Chien FC, Chen P, Chu CW, Ho KC. Org Electron 2009;10:27-33.

(b) Durben S, Nickel D, Krüger RA, Sutherland TC, Baumgartner T. J Polym Sci Part A Polym Chem 2008;46:8179-8190.

(c) Liu X, Zhu R, Zhang Y, Liu B, Ramakrishna S. Chem Commun 2008;3789-3791.

[11] (a) Kazama S, Sakashita M. J Membr Sci 2004;243:59-68.

(b) Kazama S, Teramoto T, Haraya K. J Membr Sci 2002;207:91-104.

(c) $\mathrm{Xu} \mathrm{Z}$, Dannenberg C, Springer J, Banerjee S, Maier G. Chem Mater $2002 ; 14: 3271-3276$.

[12] Huang C, Yang S, Chen K, Hsu C. J Polym Sci Part A Polym Chem 2006;44:519-531.

[13] Wang Z, Shao H, Ye J, Zhang L, Lu P. Adv Funct Mater 2007;17:253-263.

[14] Sonogashira K. J Organomet Chem 2002;653:46-49.

[15] (a) Masuda T, Tachimori H. J Macromol Sci Pure Appl Chem 1994;31:1675-1690.

(b) Masuda T, Teraguchi M, Nomura R. Polymer Membranes for Gas and Vapor Separations. In: Freeman BD, Pinnau I, editors. Washington, ACS Symposium Series 733, American Chemical Society 1999, p. 28-37. 
1-phenyl-2-(9,9,10,10-tetramethyl-9,10-dihydroanthracen-2-yl)acetylene according to the literature $[14,17,18]$, and monomer $\mathbf{1 n}$ produced a polymer $(\mathbf{2 n})$ with $M_{\mathrm{w}}\left(4.9 \times 10^{5}\right)$ in $36 \%$ yield (Conditions; at $80{ }^{\circ} \mathrm{C}$ for $48 \mathrm{~h},\left[\mathrm{TaCl}_{5}\right]=20 \mathrm{mM}$, $\left.\left[n-\mathrm{Bu}_{4} \mathrm{Sn}\right]=40 \mathrm{mM}\right)$. The $P_{\mathrm{O}_{2}}$ value of polymer $2 \mathrm{n}$ was 1600 barrers. 1n; white solid, mp 216.5-218.0 ${ }^{\circ} \mathrm{C} . \mathrm{IR}\left(\mathrm{KBr}, \mathrm{cm}^{-1}\right): 3060,3030,2963,2925,2212,1596,1492,1438$, 1270, 1042, 896, 831, 755, 689, 568. ${ }^{1} \mathrm{H} \mathrm{NMR}\left(\mathrm{CDCl}_{3}, \mathrm{ppm}\right): 7.71\left(\mathrm{~d},{ }^{4} J=1.5 \mathrm{~Hz}, 1 \mathrm{H}\right.$, Ar), 7.57-7.48 (m, 5H, Ar), $7.41\left(\mathrm{dd},{ }^{3} J=8.3 \mathrm{~Hz},{ }^{4} J=1.7 \mathrm{~Hz}, 1 \mathrm{H}, \mathrm{Ar}\right), 7.37-7.24(\mathrm{~m}$,

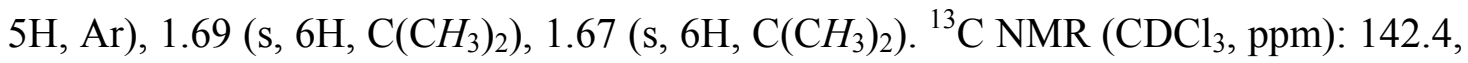
$142.1,141.4,141.3,131.6,130.2,129.2,128.3,128.1,126.9,126.7,126.7,126.2$, 126.1, 123.4, 120.9, 89.7, 88.6, 37.3, 37.2, 35.0, 34.8. Anal. Calcd for $\mathrm{C}_{26} \mathrm{H}_{24}$ : C, 92.81; H, 7.19. Found: C, 92.56; H, 7.36.

[17] Granoth I, Segall Y, Leader H, Alkabets R. J Org Chem 1976;41:3682-3687.

[18] Suzuki H, Nakamura K, Goto R. Bull Chem Soc Jpn 1966;39:128-131.

[19] (a) Shida Y, Sakaguchi T, Shiotsuki M, Sanda F, Freeman BD, Masuda T. Macromolecules 2006;39:569-574.

(b) Sakaguchi T, Shiotsuki M, Sanda F, Freeman BD, Masuda T. Macromolecules $2005 ; 38: 8327-8332$.

[20] (a) Kanaya T, Tsukushi I, Kaji K, Sakaguchi T, Kwak G, Masuda T. Macromolecules 2002;35:5559-5564.

(b) Kanaya T, Teraguchi M, Masuda T, Kaji K. Polymer 1999;40:7157-7161.

[21] (a) Freeman BD. Macromolecules 1999;32:375-380.

(b) Stern SA. J Membr Sci 1994;94:1-65. 
(c) Robeson LM. J Membr Sci 1991;62:165-185.

[22] Shimomura H, Nakanishi K, Odani H, Kurata M, Masuda T, Higashimura T. Koubunshi Ronbunshu 1986;43:747. 


\section{Table 1}

Polymerization of $\mathbf{1 a}-\mathbf{l}$ with $\mathrm{TaCl}_{5}-n-\mathrm{Bu}_{4} \mathrm{Sn}^{\mathrm{a}}$

\begin{tabular}{|c|c|c|c|}
\hline \multirow[b]{2}{*}{ Monomer } & \multicolumn{3}{|l|}{ Polymer ${ }^{b}$} \\
\hline & Yield (\%) & $M_{\mathrm{w}} \times 10^{-5 \mathrm{c}}$ & $M_{\mathrm{w}} / M_{\mathrm{n}}{ }^{\mathrm{c}}$ \\
\hline $1 \mathrm{a}$ & 42 & 5.9 & 3.6 \\
\hline $1 b$ & 49 & 13 & 3.9 \\
\hline 1c & 59 & 6.9 & 2.6 \\
\hline 1d & 40 & 6.7 & 2.2 \\
\hline $1 \mathrm{e}$ & 50 & 5.3 & 2.1 \\
\hline 1f & 43 & 5.5 & 2.3 \\
\hline $1 \mathrm{~g}$ & 14 & 7.9 & 3.7 \\
\hline $1 \mathrm{~h}$ & 12 & 5.1 & 4.5 \\
\hline $1 \mathbf{i}$ & 43 & 5.7 & 2.6 \\
\hline $\mathbf{1 j}$ & 25 & 5.8 & 2.2 \\
\hline $1 k$ & 41 & 5.2 & 2.0 \\
\hline 11 & 47 & 9.0 & 2.8 \\
\hline
\end{tabular}

${ }^{\mathrm{a}}$ In toluene at $80{ }^{\circ} \mathrm{C}$ for $24 \mathrm{~h} ;[\mathrm{M}]_{0}=0.20 \mathrm{M},\left[\mathrm{TaCl}_{5}\right]=20 \mathrm{mM},\left[n-\mathrm{Bu}_{4} \mathrm{Sn}\right]=40 \mathrm{mM}$. Methanol-insoluble product.

${ }^{\mathrm{c}}$ Measured by GPC calibrated with polystyrenes as standards. 


\section{Table 2}

Solubility of the polymers ${ }^{\mathrm{a}}$

\begin{tabular}{llllllllll}
\hline Solvent & $\mathbf{2 a}$ & $\mathbf{2 b}-\mathbf{d}$ & $\mathbf{2 e}$ & $\mathbf{2 f}$ & $\mathbf{2 g}, \mathbf{2 h}$ & $\mathbf{2 i}$ & $\mathbf{2 j}$ & $\mathbf{2 k}$ & $\mathbf{2 l}$ \\
\hline Hexane & - & - & - & - & - & - & + & - & - \\
Cyclohexane & \pm & - & - & - & + & - & + & - & - \\
Toluene & + & + & + & + & + & \pm & + & + & + \\
$\mathrm{CHCl}_{3}$ & + & + & + & + & + & + & + & + & + \\
THF & + & + & + & + & + & + & + & + & + \\
DMF & + & + & + & + & - & + & - & + & - \\
DMSO & - & - & + & - & - & - & - & - & - \\
Methanol & - & - & - & - & - & - & - & - & - \\
\hline
\end{tabular}

${ }^{\text {a }}$ Symbols: +, soluble; -, insoluble; \pm , partly soluble. 


\section{Table 3}

Gas permeability coefficients $(P)$ of the polymer membranes

\begin{tabular}{|c|c|c|c|c|c|c|c|}
\hline \multirow[b]{2}{*}{ Polymer } & \multicolumn{6}{|c|}{$P\left(\right.$ barrer $\left.^{\mathrm{a}}\right)$} & \multirow[b]{2}{*}{$P_{\mathrm{O}_{2}} / P \mathrm{~N}_{2}$} \\
\hline & $\mathrm{He}$ & $\mathrm{H}_{2}$ & $\mathrm{O}_{2}$ & $\mathrm{~N}_{2}$ & $\mathrm{CO}_{2}$ & $\mathrm{CH}_{4}$ & \\
\hline $2 a$ & 3200 & 8100 & 4800 & 3300 & 17000 & 9100 & 1.5 \\
\hline $2 b$ & 4600 & 11000 & 6200 & 4700 & 21000 & 11000 & 1.3 \\
\hline $2 c$ & 4100 & 9900 & 5900 & 4200 & 18000 & 11000 & 1.4 \\
\hline $2 d$ & 5000 & 11000 & 6600 & 5100 & 26000 & 12000 & 1.3 \\
\hline $2 \mathrm{e}$ & 2100 & 5000 & 2700 & 1700 & 9200 & 4200 & 1.6 \\
\hline $2 f$ & 3400 & 8700 & 5000 & 3500 & 17000 & 9300 & 1.4 \\
\hline $2 \mathrm{~g}$ & 2700 & 6200 & 3500 & 2500 & 11000 & 6600 & 1.4 \\
\hline $2 h$ & 520 & 1100 & 470 & 210 & 1900 & 550 & 2.2 \\
\hline $2 \mathbf{i}$ & 1500 & 3700 & 2000 & 1100 & 8000 & 3000 & 1.8 \\
\hline $2 \mathrm{j}$ & 3400 & 8500 & 5400 & 3400 & 18000 & 10000 & 1.6 \\
\hline $2 k$ & 600 & 1400 & 660 & 300 & 3200 & 810 & 2.2 \\
\hline 21 & 840 & 1900 & 1000 & 540 & 4100 & 1500 & 1.9 \\
\hline $2 m^{b}$ & 1300 & 3100 & 1700 & 950 & 6500 & 2000 & 1.7 \\
\hline $3 m^{b}$ & 1600 & 3700 & 2200 & 1300 & 8500 & 2400 & 1.7 \\
\hline
\end{tabular}

${ }^{\text {a }}$ At $25^{\circ} \mathrm{C}$ in the units of $1 \times 10^{-10} \mathrm{~cm}^{3}(\mathrm{STP}) \mathrm{cm} /\left(\mathrm{cm}^{2} \mathrm{~s} \mathrm{cmHg}\right)(=1$ barrer $)$ (the values are average values of the two independent observed values using two different membranes).

${ }^{\mathrm{b}}$ Data from Ref. [6b]. 

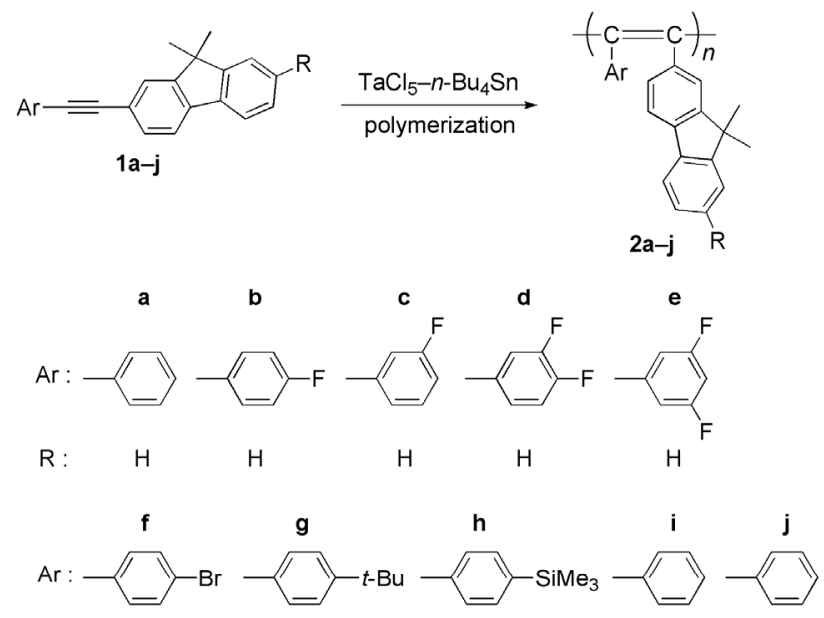

$\begin{array}{llllll}\mathrm{R}: \mathrm{H} & \mathrm{H} & \mathrm{H} & \mathrm{Br} & \mathrm{SiMe}_{3}\end{array}$
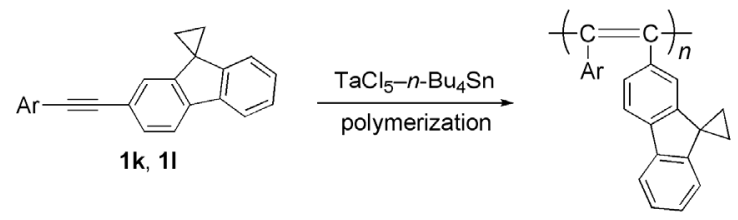

2k, 2l

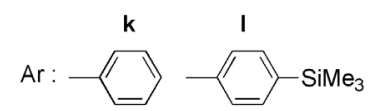

Scheme 1. Synthesis of poly(diarylacetylene)s having fluorenyl groups. 

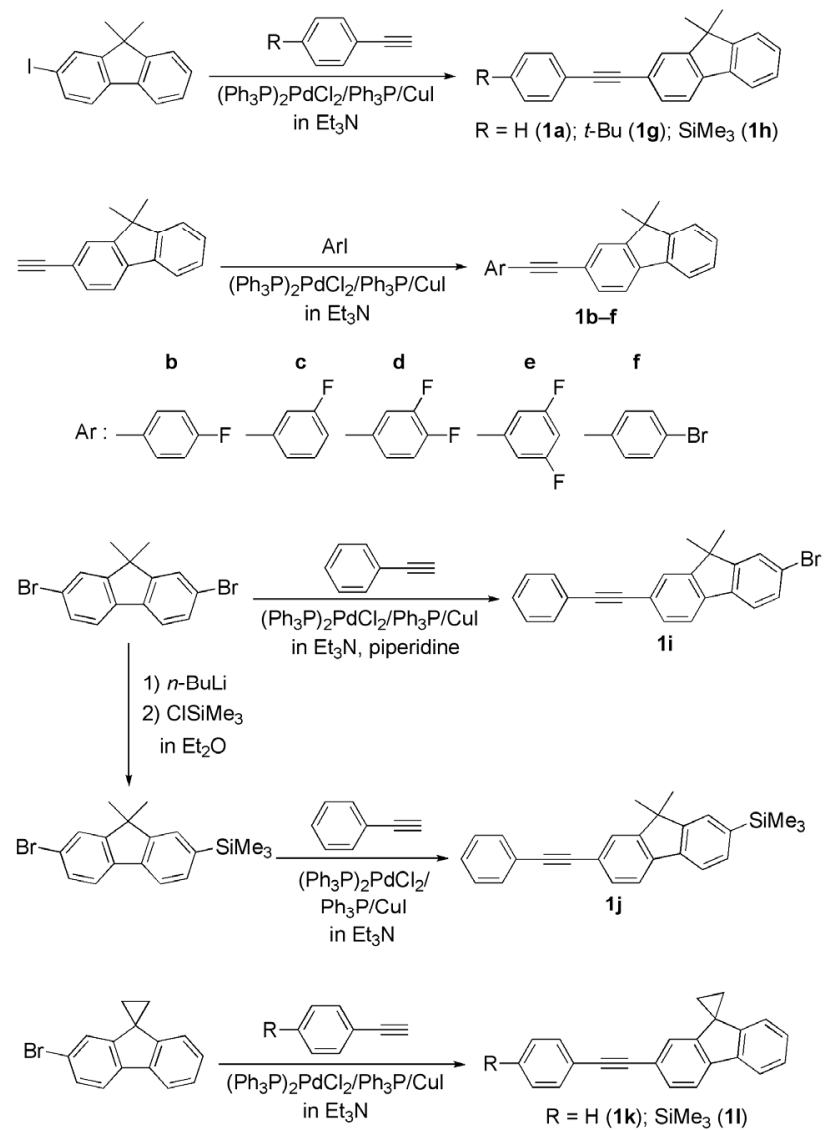

Scheme 2. Synthesis of diarylacetylene monomers having fluorenyl groups. 


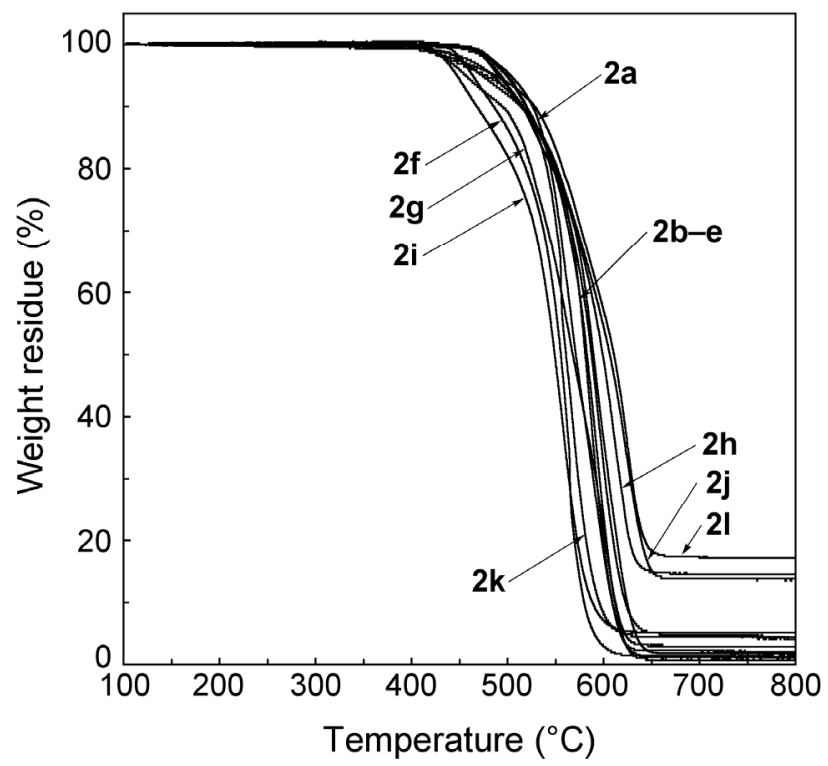

Fig. 1. TGA curves of the polymers (in air, heating rate $10{ }^{\circ} \mathrm{C} / \mathrm{min}$ ). 


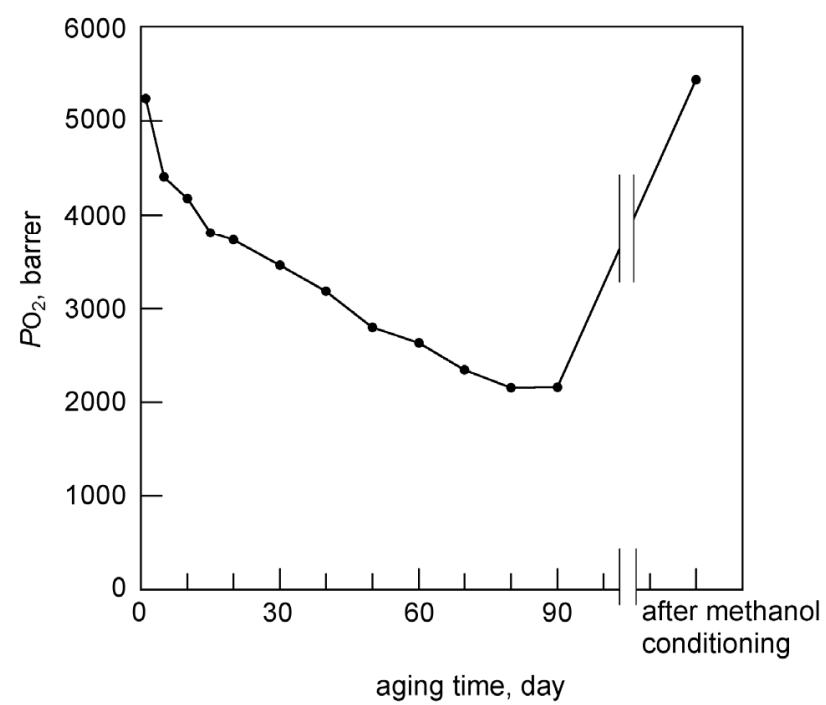

Fig. 2. Effect of aging time on the oxygen permeability of $\mathbf{2 a}$ (stored at $25{ }^{\circ} \mathrm{C}$ in air). 


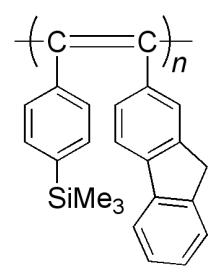

$2 m$

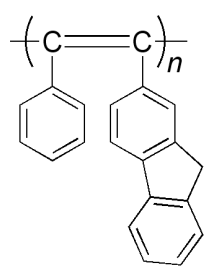

$3 m$

Chart 1. Structures of $\mathbf{2 m}$ and $\mathbf{3 m}$. 